\title{
The Female Target: \\ Digitality, Psychoanalysis and the Gangbang
}

\author{
Diego Semerene ${ }^{1}$ \\ Brown University, USA
}

\section{doi: 10.5937/comman11-11218}

Abstract: The essay culls from classical texts and personal experiences of libertine intimacy with strangers to address age-old academic blind spots regarding group sex as a recurring fantasy and sexual practice. What is brought forth is a Freudian and Lacanian analysis of the relationship between contemporary desire and digitality through "the gangbang" as articulated on digital platforms. The focus is on digitally-assisted gangbangs involving a transvestite and several heterosexually identified males, and what such events reveal about digital media's and heterosexuality's demands. The author argues that this sexual configuration is a re-enactment of "the great misdeed", which Freud recounts in Totem and Taboo as the mythic primordial killing of the Father by the band of brothers. This symbolic occasion is described as the genesis of social organization and re-emerges as a form of mourning the disappearance of the fleshly body as new media turn it into digital code. Such a codification of the body awakens anxieties around the fictitious conflation between penis and phallus. In the face of the digital, man outsources his phallic power, which is suddenly required to be represented corporally at all times, to a virtually organized multitude that is willing to sacrifice freedom in the name of the group, and the legitimation of hetero-masculinity that it can presumably grant. The gangbang also appears as a digitally mediated opportunity for old fantasies of aggression and expiation to articulate themselves without putting the white male heterosexual body on the line.

Keywords: psychoanalysis, digitality, digital culture, rape culture, gangbang, group sex, trans, cross-dressing, cruising, death drive

\footnotetext{
Contact with author: diego.semerene@gmail.com.
} 
"Because there are three, one of them can watch what the other two are doing together. (...) Or, because there are three, two can worry about the third, for instance the one lying down."

\section{Lydia Davis, The Cows}

\section{The Phallus as Collective Trompe L'œil}

In the summer of 2009, I attended a conference in France entitled The Unconscious and Sexual Identity, organized by a Lacanian research group. The room was filled with renowned panelists, mostly practising psychoanalysts, and the moderators were celebrities in the field. The ideas raised were theoretically fascinating, but the comments were anodyne, and the discourse rather technical. For an intellectual space whose language was supposed to be desire, nothing indicated that we were speaking about bodies and bodily practices. It was as if in the name of rigor, erudition or decorum, concepts had to be handled with latex gloves - no matter, or precisely because of, how messy they were, as if not to taint, or implicate, the bodies of their handlers.

That is until a lone woman in the audience raised her hand and punctured the protocol. Her very physicality felt conspicuously out of sync with the wellcoiffed multitude that surrounded her. Her red hair was too voluminous to be tamed into place, her skin slightly weathered, her demeanour unapologetic. Without hesitation, she delivered a response about women's bodies being mediators of sex between men, heterosexuality's most fundamental schema, by claiming that feminine mediation became most literal in the gangbang.

In a conference about sexual identity, on its third day, that had yet to consider something other than the heterosexual desire of the couple, apart from its supposedly opposite homosexual counterpart, which simply "confirms" it, the woman's speech caused no visible commotion. Yet it worked as a Pandora's box opening, the kind that makes others feel guilty, if not intellectually dishonest, for not having initiated such a move sooner. One comment, and its straightforward delivery, introduced the body as a living organism among many 
- potentially ugly, porous, dishevelled, disgusting, leaky, horny, smelly, ${ }^{2}$ and uninterested in its intactness -into the domain of a legitimate object of inquiry. ${ }^{3}$

The woman's comment cracked open the limits of the discourse as its recognizing the gangbangable body - the body as gangbangable - meant a recognition of the body in practice, that is, the body that wants too much, too much and all at once, the body that wants because and despite. To see this body and to speak it is to expose oneself as an animating agent of such a body. It is to refuse the omniscience and distance associated with a masculinist position, which we may call écriture masculine: a masculine way of writing bodies out without risking disclosing the status of one's own. To render the gangbang public meant implicating her self in a sexual multiplicity that is loud and obtrusive, that is, in the terrain of the unavowable, the disgusting, the not-so-catholic noises (Giard, 2014).

Virginie Despentes (2006) recognizes in collective male laughter a seminal sign of the brotherly multitude that enacts a gangbang, the brotherhood on which the gangbang depends, but also the general (rape) culture - a methodically arranged gangbang in its own right. Despentes notes that man's attempts to live up to the myth of the phallus always fall short, regardless of the various technologies he may use to mimic a convincing phallicity, such as artificial limbs in their literal and symbolic forms (Despentes, 2006: 37). This phallic failure thus begets stratagems of denial and the interpellation of the group as a way to masquerade absence, inability and frailty.

The phallus depends on a complex network of technologies to hold itself up in a spectacular non-fragmentary fashion. One way of forging a believable phallus, or a sense of it, is through the coming together of "a number of men" who unite "in strength superior to any single individual and remain united against all single individuals", which amounts to the constitutive dynamic of civilization (Freud, 2011: 53). For Freud, "artificial limbs, so to speak, [are] quite

\footnotetext{
2 Gayle Salamon, via Merleau-Ponty and Freud, reconsiders identity and the drive, and sexuality more generally, as an atmosphere, an odor, a sound, or a leading towards which points to past and future and spans multiple temporalities (Salamon, 2010).

3 The body is, for Foucault, "a volume in perpetual disintegration" (Foucault, 1977: 148). Its condition as always already disintegrating gains explicit status with online representation of the cruising body, as it is pulled apart and back together, cropped into limbs and re/de-contextualized by the self who makes it anew and the other to whom such bodily compound is supposedly addressed. Fictions of intactness are at the center of Guy Debord's concept of spectacle in a way that echoes the digital sex session as a specular and spectacular technology of disavowing the fragmentary existential condition of the body, evolving "into a world where even the deceivers are deceived" (Debord, 2014: 1).
} 
magnificent when equipped with all his accessory organs; but they do not grow on him [on man] and they still give him trouble sometimes" (Freud, 2011: 59). Following this logic of gender configuration, Preciado sees the impossibility for man to ever nurture a link of solidarity with someone other than another man (Preciado, 2008: 318). ${ }^{4}$ This solidarity, that of the brotherhood that the gangbang displays so palpably, is exclusionary, as all solidarities, and rests on the inferiority of women, enabling men to laugh among themselves the loudest laughter, made louder through numbers.

Despentes calls collective rape, also driven by the gangbang ethos of nonconsent and masculine multiplicity, masculinity through multiplicity, a war strategy that promotes one group's virilization over another (Despentes, 2006: 35). Man's soldier-ness is thus literalized in the temporal juxtaposition that the gangbang performs: The battalion is not dispersed through time, kinship and geography (from father to husband, for example). It is not even housed inside an inbox with thousands of emailed photographs from potential, rejected and done-and-discarded digital lovers, but all at once in the same space with a clear and palpable target keeping their multiplicity from becoming one (Despentes, 2006: 37). The gangbang is thus an apparatus of death-driven brutality in the repertoire of what Haver calls orthosexuality (Haver, 1996: 3), and Javier Sáez and Sejo Carrascosa name the feathers of heterosexuality, alongside genocide, nuclear terror, racism, misogyny, sports, engines, alcoholism, gangs and risk (Sáez \& Carrascosa, 2011: 119). ${ }^{5}$

For Jonathan Dollimore, the terrain of the unavowable - the "not-socatholic" configurations, temporalities, noises, and smells - too often suggests "anxiety if not aversion" (Dollimore, 2001: 367). This surfeit of a body (of orifices, blood, piss, vomit and overpowering hunger), excised from theoretical work and from conference rooms alike, shares a kinship with "one of the most significant repressions of academic writing about sexuality," namely, disgust (Dollimore, 2001: 367). Disgust, which is excessive, as it trespasses on the limit of good taste, has a critical organizing function for sexual identity, practice,

\footnotetext{
4 Jack Halberstam notes the complementary relationship between men in his reading of the film Dude, Where's My Car? (Leiner, 2000) arguing that before the menace of castration and humiliation, the dudes face their obstacles "as a team, a unit, a collective, and each functions as the other's phallus, or weenie". Patriarchal power takes, then, at least two: "one to be the man and the other to reflect his being the man" (Halberstam, 2011: 66).

5 Sáez and Carrascosa also include "shouting," "pushing" and "spitting" in the roster of the "obsessive rituals" of heterosexual masculinity (Sáez \& Carrascosa, 2011: 120).
} 
politics and discourse: "the sexuality of some straight men is organized around a barely concealed contempt for, but also a fundamental disgust with, women. Crudely, they fuck them despite - or because of - not much liking them" (Dollimore, 2001: 368). ${ }^{6}$ In a gangbang scenario, the bonding of the brothers is achieved through the formation of an ambivalent target - it is wanted and reviled in unison, and its desire must be explicitly addressed through and for the group, as its annihilation (Dollimore, 2001: 371).

There is a silent etiquette that governs sexual noises and academic conference rooms, which not only polices the excitation/disgust divide, or composite, but also genders them: Loud moaning feminizes the subject as it indicates the 'too-much' of desire that the subject is simply too weak to contain. The gangbang ensures that excess of desire is evenly distributed by the number of men in the space, whereas the feminine body is made extra vulnerable to libidinal excess by being that much lonelier in a room full of strangers. It is as though in a war whose victory and defeat are pre-determined by the sheer quantity, or asymmetric force, of those on one side and the sole target on the other side. That is, precisely the type of war currently fought across the globe, whose drone logic turns the battlefield into a hunting ground, doing away with the traditional relationship between sovereignty and borders.

Contemporary digital culture demands a certain priapism from bodies. This is a perpetual interpellation of bodily visibility that male subjects have historically not "enjoyed," or have historically not been demanded to put forth. Selfdisplay, when it comes to clothing, for instance, was progressively renounced by male bodies starting in the $18^{\text {th }}$ century through Industrialization in what scholars have called The Great Masculine Renunciation. This meant that women became responsible for marking and flaunting class and gender difference through adornment, granting men protection from the perils of self-exposure. Masculine bodily presentation became progressively self-effacing, sober and inconspicuous: the very cut and colours of the male suit have remained virtually unchanged for hundreds of years when compared to women's dress. ${ }^{7}$

\footnotetext{
6 Susanna Paasonen remarks that heterosexual pornography tends to revolve around "female bodies as desirable yet somehow disturbing, disgusting, or even abject". I would argue that the abject-ness of the feminine object is a precondition for it to reach desiring status, which, as Paasonen suggests, works to maintain a safe distance between subject and object through disgust so that the first cannot be swallowed by the latter (Paasonen, 2011: 216).
}

For a critical account of The Great Masculine Renunciation (see Silverman, 1986). 
We can thus see that there is something quite new and unsettling for men to suddenly, through the demands of constant digital representation of their bodies (that ultimate site of phallic failure), find themselves interpellated by the position of being-looked-at. When they are finally asked to represent themselves bodily, even if such a demand does not do away with their ability to look, new strategies for managing the threat of phallic undoing emerge. Furthermore, men are forced to come up with new ways to over-compensate the emptiness of that undoing, as well as new narratives for denying the sameness that the phallus aims to mask.

The forging of the mirage of the phallus goes necessarily through the group, not only in the scene of the gangbang, which the digital makes practical, if not probable, but in the many ways men pose for selfies, which consistently involve pointing at other men in the frame (particularly in workout culture selfies): men making sure their hands are always rigid, never resting, never pointed at themselves but at the bodies of their fellow men. In the absence of other men, social media selfies of men often include phallic props, such as these men's cars, trucks, alcoholic bottles, dogs, joints, bongs or protein supplements. ${ }^{8}$

In a gangbang setting, the perpetual rigidness is both material, through the help of active accomplices, and aural, through noises of a specific kind - like the sound from slapping the $(\mathrm{t}-$ ) girl on her bottom, the audible comments to the other men, and their collective laughter. These noises are elicited as if to remind the men that they are a brotherhood but also individuals, albeit circling around the same target: They have not merged into oneness, which would feel incestuous, homosexual and ensnaring. ' The exchange of such sounds works like a call-and-response game where the other's reply will always be a confirmation of what sense the sex scene has for its agents: a "we are all in this together", which further alienates the ( $\mathrm{t}$-) girl and puts her in her place of ensnarement.

Catastrophe, or the dreaded failure to abide by the fantasmatic regulations of heterosexual intercourse, is never too far away, as even the cleverest necropo-

\footnotetext{
8 For Alison Winch and Jamie Hakim, an obsession with muscular male bodies online is necessitated by a politics of austerity that literally strips men of being able to boast material goods. They are left with their bodies to work on and display as a plea for symbolic legitimization and cultural belonging (Winch \& Hakim, 2017, forthcoming).

9 The complete loss of individuality is precisely one of the most fundamental necropolitical technologies granting men in a position of power - Western heterosexual white cisgender males - the luxury of omniscience and omnipotence. Entire populations are managed, and marked to die, through the very process of losing their status of human subjects and becoming masses to be occupied, through surveillance, migration, institutionalized violence or drowning with their sinking boats (see Mbembe, 2003).
} 
litical techniques risk malfunctioning. Failure hovers over, always awaiting, in the process of undermining the sex scene (Giard, 2015). The disgust that the figure of the gangbang is supposed to elicit in a woman in the general culture is constitutive to her, for she is supposed to yield, not yearn. Her response to the spectacular cowardice that brings joy to the supposed agents of the scene must be one of only partial consent, which makes the gangbang an essentially rapelike spectacle. Due to the sheer difference in numbers - the active multiplicity against one single presumably passive body - confirms, in the most scopophilic ways, the asymmetry that codes, and drives, the scene of the gangbang. The gangbangable body cannot completely long to be gangbanged, or, at least, shall not admit to it. Her loud moaning comes about as the aprè-coup of man's ability to make woman speak not her pleasure, but the brutality of their own bouncing off of her.

\section{Caulking, Shutting, Sealing: The Hole and/in The Frame}

The introduction of the gangbang in the conference room that worked as a preamble to this essay spawned a new sense of academic integrity for me, one that allowed the body proper, the body in practice, my own cross-dressing body of the night before, my body of each and every night if sexual enjoyment is to happen at all, the nocturnal body of the t-girl for solely sexual purposes, my body, to be present, to be available, to be heard, to be smelled. Ironically, this body is missing even in the pornography of every night, in my bedroom and on my screens, obstructed by the ocean of men trying to penetrate its every hole, bust the female target into pieces, or piece her into a target. In gangbang videos and photographs, all one sees, after all, are men's backs and buttocks obstructing the visual evidence that a woman is there somewhere, if anything, to keep the proximity of the male bodies from gaining homosexual status. If my only entry point into this economy of heterosexual violence seems to be to dress up as a girl and claim trans not as a stable identity, but as a technology, this also tells us how much the digital discloses the fragility of the concept of sexual difference. The popularity of my online ads, where a t-girl looks for straight men for a gangbang, points to the status of "woman" in the digital age, or perhaps to the loss of woman's body, which is mourned into the broader, less bounded, category of the target - which covers a larger area. Here the object (of desire) is exposed, in all of its psychoanalytic glory, as a semblance, not a substance. 
Scholars have argued that the digital is rooted in a binary logic in its backend, the actual code that mobilizes data flows and makes images appear in highly pre-determined ways. By the time we interact with the manifested digital content, much like what happens once sexual partners arrive at a sex scene like a gangbang, all the chips are down. Tara McPherson (2012) has referred to this binary structuring and archiving of data as a lenticular logic where two things are never true at the same time, but remain necessarily segregated. Yet at the level of affect digital networks are experienced mostly in a highly privatized fashion, which can lessen the surveillance of the superego (while raising other more institutionalized types of surveillance), allowing for desire to derail itself back to its original queerness and away from its normativizing, orthodox and orthopedic channels.

The abundance of the male butt(hole) in the frame of gangbang pornography is excused as that excess is understood in the name of the overarching objective of the scene: the utilizing of woman's holes as if to deny one's own, or rather, the spectacular confirmation of woman as a collection of holes to be handled by a collection of men. The gangbang is an intimate (re-)erection of borders. Such tinkering with a hole-infested body to be managed by the group ends up producing the visual occlusion of the body in question in favour of a visual overabundance of the male hole and its vicinity. If the target is virtually kept from view, it must have been properly hit, claimed and occupied. At the level of the very frame, a scene that is meant to perform and enhance the intensity of an invincible phallus - and to confirm the passivity of woman - her lack of wholesomeness - produces an undeniably homo-sexual visual spectacle. Through the devouring of woman's holes (or, of woman into holes), which leads to the curious exhibition of the male hole and its provinces as a collective, another fantasy of hermetic masculinity is told.

Since the male ass may serve as evidence of a universal hole (the anus has no gender, no race, no trans or cis status), it is generally disavowed through laughter and absence from the field of vision in non-pornographic conditions. ${ }^{10}$ Sáez and Carrascosa argue that male heterosexual subjectivity is based on a (male) body whose mouth can be open but whose ass must be sealed, whereas women

\footnotetext{
${ }^{10}$ On laughing as a violent kinship operation between men to the detriment of women, or femininity more broadly, as it plays out in digital trolling see Phillips (2015).
} 
can prop their asses open provided their mouths remain shut (Sáez \& Carrascosa, 2011: 73).

The anus and its vicinity function as signposts for this universal condition, that is, of the human body as an open wound, unbounded and perpetually exposed, that transcends genderization and other forms of border control. Sáez and Carrascosa note that the skin has pores and, through them, water is exchanged with the environment. The stomach and intestinal walls are also porous, and it is thanks to that very porousness that the nutrients of food can be assimilated by the body. As a matter of fact, they argue, the survival of living organisms depends on their systems being open (Sáez \& Carrascosa, 2011: 92).

Control of the anus, which is literally framed by the buttocks, may even mark "something like a point of subjectivation" in the constitution of the subject, which the gangbang aims to shut, like the fixing of a leak, in woman, and disavow in men - despite visible evidence to the contrary. The anus and its vicinity overtake the frame while the men caulk the very small anatomic evidence that props up naturalized fictions of a material female lack - the vagina, or its "opposite," in the case of the t-girl (these two figures, with such different genitals being so interchangeable in the scene of the gangbang is quite telling), as if emptying their own anal-existential anxieties by filling woman up to the brim. ${ }^{11}$ The heterosexist system hinges on the magnification of a small genital difference so that woman functions as the absolute other (Sáez \& Carrascosa, 2011: 119). ${ }^{12}$ As one potential gangbang participant from Craigslist once put it, "I can beat that pussy up and I love to DP [double penetration] and really get that slut airtight". The organizers of a Bay Area gangbang recently advertised on Fetlife highlighted plans for a triple penetration (woman's mouth, vagina and anus filled by penises) and entitled that event an "Airtight Party". And if gay gangbangs are often scenes where pharmacological drugs such as crystal meth and poppers are meant to relax the feminized bottom's sphincter we can presume that the looser the target the more room there is for it to be filled.

Human Rights Watch published a report on Iraq in 2009, which described a gay extermination technique that involved cementing the victims' buttholes

\footnotetext{
${ }^{11}$ In a clarification that can help us understand the interchangeability of feminized bodies counting as the female target, Jordan Crandall reminds us that drones, that ultimate embodiment of digital violence, have no windows, that is, what matters is their function - what they can do for/to us - not what is inside them (Crandall, 2011).

${ }^{12}$ For Fethi Benslama, concerted violence tends to ensue when rupture in processes of identification, or its threat, specifically involves fellow beings who are ultimately rather alike (Benslama, 2016: 101).
} 
with a potent glue of Iranian provenance, which could only be extirpated with surgical intervention. The gay men would then be forced to drink diarrheacausing medicine and implode in a type of involuntary fecal self-bombing devoid of any martyrdom. The torture and subsequent extermination would be captured and promptly viralized through cell phones. Interestingly, the act does not infect the assailants with the annihilating gayness that they impinge on their victim, as if immunity to the feminizing lack could only be granted through its violent pegging onto someone else - ideally by a group. Here the infectiousness of lack is contained and performed jointly through a physical projection that literalizes a symbolic - and founding - projection (of lack) already made in the unconscious: it is woman who does not have it. A similar logic played out in Libyan dictator Muammar Gaddafi's downfall as he was violated by a sealing of sorts - and also memorialized on video (extending the kin-making to fantasmatic brothers who may not have been physically present to witness it) - by rebels shoving a stick up his ass. The identification between "gay" and "anal sex" may be complete, but the torture centres exclusively around the bottom gay, or the psychic labour of containing gayness in bottom-ness. It did not occur to the Iraqi militia to castrate top gays or to extend gayness to those who penetrate supposedly gay bodies (Sáez \& Carrascosa, 2011).

I once brought to the attention of my Gender Studies undergraduate students the fact that a lot of them felt compelled to preface their blog posts with "as a heterosexual male..." before expressing their opinions. One ("heterosexual male") student, then, emailed me with an account of the following game, which he described as a common elementary school prank between boys, to illustrate his justification for the self-identificatory prefacing: it "revolved around one student placing his hand on a peers [sic] shoulder. For however long the hand was left on the kids [sic] shoulder determined how 'gay' the person was. The game may seem harmless at the time, b/c it becomes a competition to remove the person's hand from the shoulder as soon as possible. But when the punishment for being slow or not reacting determines 'gayness' probably stimulates the crazed out defense mechanism that probably follows kids into adolescence." (Personal communication, September 27, 2011).

In the gangbang, as the men act diligently to plug woman's openings, to tag openings as woman's (whether their bearer literally be cis or trans, or gay bottoms - the necropolitical is staged through clustering bodies into "populations") femininity carries a toxicity similar to the transmitting powers of gayness in the 
children's game described above: a hazard to be managed before our exposure to it enlists us as one of them. When "we talk about an object of desire, we are really talking about a cluster of promises we want someone or something to make to us and make possible for us" (Berlant, 2006: 20) As such, femininity and lack are zoned off as the dangerous properties of the other while the male self is further engulfed as a body amongst other male selves, guaranteeing a collectively established signification to "male self" beyond a shadow of a doubt: if he is gay I am gay and thus if he is not I am not. The male self is thus able to share not just woman, or the labour of tagging a gay body as unquestionably other, but the anxiety, and psychic precariousness, of maleness in general - a category dependent on the constant and brutal management of corporeal borders.

The anus as a site of heterosexual undoing is tamed in the gangbang through the violent mission enacted towards the female target, said to be the driving core of the congregation, like a drain, which excuses whatever exposure of normally disavowed (male) lack, or hole-ness. The omnipresence of the male ass in the frame in gangbang pornography and in the scene of the gangbang in situ points to a flaunting of man's privileged position, the same kind of urge to display one's fictitious immunity to lack - produced and celebrated by the group - that governs so much online violence, such as harassment, stalking and trolling. Since the target of men's gangbang assembly is so loudly (re-)inscribed, the practice cuts them some slack, forgiving certain visuals and acts that may, in a different setting, throw them into the perceived lack-ness of the homosexual. Were this undoing ever to take place - if the female target went missing, or failed to do its job - we could expect new differences to be forged amongst the bodies that were left to count so that new targets, and new brotherhoods, could emerge.

Masculinity is, clearly, not in the genitals or chromosomes, but in the successful, and bound to at least partially failed, maintenance of an impenetrable body. In the images that document and represent the gangbang, the gangbang's fragments, the heterosexual male body has presumably never come this close to being penetrated, as men boast of their unused cavities, brushing them against the very tools that would potentially rupture their fantasmatically sealed holes, and perhaps courting them - as if to display their successful brush with their own undoing, or death. They know they will survive because by the time woman arrives she is already dead. 


\section{The Digital, The Multiple, and 'The Great Misdeed': The Gangbang As Bereavement Ritual}

The strategy of phallic production through male multiplicity is called upon at a time of phallic crisis that digital culture launches by demanding that men's bodies be exposed and exchanged constantly. Man has probably not been in such a vulnerable position in relationship to his physicality since "erecting himself from the earth" and adopting an upright position, "which made his genitals, that before had been covered [by a bent-over gait], visible and in need of protection" against feelings of shame (Freud, 2011: 66). ${ }^{13}$ This demand can only sustain itself through representation (digital or otherwise), outsourcing (to racialized others, to the group, or to weapons), and pre-emptive refusal to perform, or to perform alone. The gangbang's male multiplicity feasting around a t-girl's body may, for example, project not just lack, but the penis specifically as a potentially malfunctioning tool as woman's exclusivity since the feminine body in the middle bears a malfunctioning penis: The devouring of a disarmed bomb, or the salvaging of a downed drone. When drones crash, in fact, their owners are often reluctant to admit proprietorship. ${ }^{14}$ A Craigslist lover once put it in a text message, as he inquired about my own penis: "I like to see it flapping out of control while I'm in control!"

While pornography itself is based on an erection-penetration-ejaculation circuit culminating in the money shot, contemporary digital culture is driven by an erection-erection-erection circuit with the demand for actual penetration anxiously hovering over it. As a networked system with an endless potential for cruising, from one hyperlinked node to the next, the Internet fosters and sustains arousal. It is only invested in its resolution inasmuch as it gives way to its re-ignition. This drive towards an excitation that never finishes echoes a neoliberal ethos that fits nicely with fantasies of invincible masculinities. Websites need traffic, not respite. This is a promise only a team of agents - an entire army of drone pilots - can keep, with its multiple bodies, turns and shifts. There are ways beyond the group, or the gangbang, to manage the weight of the priapistic demands of the digital, and neoliberal ideals of productivity - Sáez and Car-

\footnotetext{
${ }^{13}$ Freud describes this moment as "a time when visual stimuli became paramount," and a new life form began. He also associates this with a lowering in value of the sense of smell. (Freud, 2011:78)

${ }^{14}$ For a poetic-political reading on the erotics of drone crashing, "The shiny drone, the smashed drone", see Crandall (2011).
} 
rascosa suggest fisting as a technique for the perennial erection of a genderless member, for instance. The fist and the anus show sexual difference, which dominant systems depend on, to not be "so evident, and perhaps not even relevant" (Sáez \& Carrascosa, 2011: 111). ${ }^{15}$ We can see one way of dealing with the digital injunction for phallic exposure in the frequency with which men post photographs of themselves working out online with hashtags such as \#loading, \#beasting and \#beastmode, along with peptalk-like captions that seem to solely address other men, not women, and refer to their bodies as profit-driven machines immune to feeling. The hashtag here assumes the feminine function as a kin-making device linking men but only remotely.

The viral broadcasting of rape also works like an increasingly popular way of managing the burden of priapistic circuits. Here certain men are quick to not only attack, but also boast about committing assault, documenting their crimes and publicizing them. This is true for the Steubenville rape of 2012, when members of a football team "dragged a 16-year-old girl almost naked from party to party", while she was unconscious and promptly "fondled, fingered, and urinated on" by at least two boys, and this was then shared by many more through the Internet. A larger group, dubbed the 'rape crew', took pictures and videos of the dead living body, which they then posted on Twitter, Facebook and Instagram. In one particularly disturbing video, a young man cracked jokes about the ongoing actions, claiming "they raped her quicker than Mike Tyson raped that one girl” (Chun, 2016: 97).

We see a similar logic in many other cases where boys cannot keep themselves from raping, but very specifically, from sharing the rape, when making the rape public through viral broadcasting becomes the most fundamental aspect of the act. The pleasure seems to be in the flaunting of the other's body as a gaping wound for which one is responsible, which promptly takes the gaze away from possibly surveying one's own body and the potential wounds, or holes, inherent to it. To rape collectively, to rape with and for the network, to gang-rape digitally, becomes more important than any physical, or sexual qua sexual, pleasure the abuse could trigger in the rapist. Stanford University rapist Brock Turner, who served three months in jail for his crime, took the time to snap a picture of his victim's breast mid-act to share with his swim team bud-

${ }^{15}$ Paul Preciado also points to the fist, and any human limb, as equivalent (if not superior) to the penis' sexual function (Preciado, 2000). 
dies. The Vanderbilt University rape case also illustrates this, as Brandon Vandenburg and his friends literally gang-raped an unconscious girl and still took a video and pictures to share with those who could not take part in the event live. Images of surveillance cameras that became widely available on Youtube, showing the young men dragging the unconscious girl's body (the girl is often unconscious - would it matter if she was trans, a gay bottom or a doll?) from place to place add a chilling layer to the story, as reaching some kind of fantasy of notarized airtight masculinity is worth more than one's freedom. One is willing to risk anything but to remain outside masculinity guaranteed through and for the group.

In 2016, a group of around thirty men raped a 16-year-old girl in a favela in Rio de Janeiro, Brazil. Thirty was still not enough to assuage the men's drive to gang-rape, as they promptly shared images of the violence online, most notably on Twitter, where a video of a man sticking out his tongue in front of the girl's bloodied body/corpse, post-rape, was accompanied by lines such as, "this is where the train passed by hahaha, these chicks are too easy", and, "hahaha the train really wrecked this one" (Moraes, 2016, my translation).

The highly precarious ways of managing the burden of priapistic circuits in the digital, exemplified above, refer us all the way back to what Freud described as the "great misdeed" that laid the foundation of human sociality. Freud explains the ambivalent relationship contained in sacrificing the Father by linking his murder with the death of the totemic animal in clans where the killing of such an animal was so occasional that when it happened it was undergirded by a holiday ethos, a ritual of "loud festival gaiety" that accompanied the temporary lifting of a prohibition. In a culture of rape, it seems as if assaulting the female body, or the body made female through assault, would hardly constitute an event such as the parricide described by Freud. In such a dynamic of gendered, or gendering, banality of violence, the thrilling holiday ethos lies in the circulation of the act of cruelty, not in the act itself. The flow of data here mirrors and dramatizes the violent rush put forth through what certainly can feel like unlimited bottomless dissemination.

The murder in Freud's account of the great misdeed, or its mourning, could only be carried out by the various members of the group, never by one single individual. The effects of the feast could thus be multiplied at the level of fantasy and the guilt involved was promptly relieved through sharing. If the sense of 
individual force gains priapistic dimensions through collective circulation, the guilt derived from violence simultaneously diminishes. A sense of kinship was reiterated as these brothers in death celebrated and lamented, as they dreaded some kind of retribution for having killed the animal. We can see how electing the animal as the object of sacrifice enabled the murder to be repeated infinite times, whereas a Father's death is unrepeatable. This brings forth a convenient economy of substitution where there will always be an easily accessible target to hit, which is at play in the interchangeability of girls and t-girls in the gangbang scene. In this manner, the t-girl appears as the ideal object of desire, able to trigger the kin-making destructive response from the gangbang men, now brothers, while keeping the subsequent need to mourn to a minimum.

In Freud's scene, the brothers may have joined forces to overthrow the Father, but they were still each other's rivals among women as the post-murder guilt drove them to institute the prohibition of incest, "perhaps the most maiming wound ever inflicted throughout the ages on the erotic life of man", turning their eyes away from the mother and towards representatives of her semblance, that is, women more broadly (Freud, 2011: 74). ${ }^{16}$ Totemism worked as a palliative settlement, helping the brothers to deal with the anxiety stemming from having killed the Father by keeping his surrogate - the totemic animal - safe, while justifying that, had the Father treated the brothers themselves as they treat the totem, they would not have had to kill him. It was thus in death that the Father was most obeyed.

Since, for Freud, the totemic animal is a substitute for the Father, this scene of kin-making murder and mourning illustrates not just the interchangeability of objects-cum-targets (and certainly, of their materiality) but also children's contradictory feelings towards the paternal figure, who is both venerated and despised, "envied and feared" (Freud, 2013: 129). Freud's account and expansion of the Darwinian conception of the primal horde suggests that a new form of technology, "a new weapon", might have enabled these brothers to finally rebel against a Father who kept "all the females for himself and [drove] away the growing sons". This new technology would have brought the brothers a

\footnotetext{
${ }^{16}$ A Facebook posting by a recent Craigslist lover, ahead of the 2015 Superbowl, illustrates some of these points, "Having played both soccer and football, I recently happened to witness and be a part of something that would not be in my best interest to mention in detail, but what I got out of it is what my coaches, bosses and fraternity have preached to me all throughout my life...no one person is bigger than the team...no one person should ever feel or act as if they are... a team is always one... one focus, one goal, and should always work as one, both mentally and physically" (Personal communication, 2015).
} 
feeling of superiority, giving them the push needed to put their feelings (of violence) into practice and eat their victim raw, like "cannibalistic savages" (Freud, 2013: 129).

If we extend the great misdeed further as a blueprint for the thrilling dynamics at stake in the gangbang scene, we can see how this switch of targets from the actual Father to his bestial representative suggests that the t-girl is a rather seductive target for the gangbang feast. The t-girl's dubious status - simultaneously is and is not woman - makes it particularly easy for men to toggle between the appropriateness of the target as an object woman enough to merit destruction but not woman enough to produce guilt. Let us also remember that by the time the t-girl enters the scene, her penis is already dead. In fact, the deadness of the penis, at least in its status as a fleshly surrogate for the phallus, is the t-girl's raison d'etre. The fashioning of the gangbang's target as a t-girl at once dramatizes the eminence and irrelevance of sex in the drive to destroy and to repair. Genitalia, that presumed gendering guarantor, are either blocked from view (by the multitude of male asses in the frame and the fact that only the target's ass can be used) or rendered nonsensical, or rather, non-lenticular (many things are true at once). The gangbang then is not a parricide or a matricide; it is a violent response precisely to the anxieties that gender's lenticular logic begets.

For Russell Grigg (2014), mourning is, in fact, not about losing the object but commemorating it. He stresses the way in which mourning insists in preserving the semblance of the object - considering its materiality may be missing, as in death. Mourning is, then, a commemoration of semblance (of smells, of mannerisms - what counts as the object). It is crucial that this commemoration be at once private and public, as we can see in the various rituals of bereavement - including, I am arguing, the gangbang - and totems such as the AIDS Memorial Quilt. Thus, while, for the congregating men, the gangbang can be a perfectly liminal site for a primal settling of accounts in the public and the private, for the gangbanged subject herself (the t-girl in the context of this essay) it can be an opportunity to render her private position public, to seek legitimacy by inscribing her woman-ness publically (yet privately), particularly when her woman-ness is not sufficiently passable to be taken out into the socius somewhat safely - as is the case here, with t-girls who only cross-dress for the purpose of sexual encounters with heterosexually identified men. 
While the great misdeed revolved around the killing of the Father, Melanie Klein (1988) reminds us that human subjectivity is founded on violent fantasies of destruction directed at whoever the caretaker is, along with feelings of guilt for having destroyed, even if just in fantasy, that which guarantees one's survival. I am arguing that while the great misdeed was a highly gendered event, the affects that made it possible, along with the affective reactions that it caused (mourning, guilt, and destructive reparation), speak to an actually non-gendered drive to destroy and replace, to kill (as much as possible) and to mourn (as little as possible), to congregate and to topple, to ruin and to repair, and, most importantly, to make reparation by ruining - by ruining again.

Sáez and Carrascosa argue that sexual binarism and the myth of the heterosexual-reproductive couple cannot operate in the domain of the anal, which defies its genitally dependent logic. The anal also questions another binarism, the one that divides human beings into heterosexuals and homosexuals (Sáez \& Carrascosa, 2011: 56). They refer to Paco Vidarte's ethics of anality (analética), a counter-cerebral ethics of solidarity "more urgent, honest, carnal, cruising, animalistic, prone to the basic necessities of those whose asses stick up in the air (...)" (Sáez \& Carrascosa, 2011: 66). For Vidarte, this ethics would suck in everything and give nothing back in exchange, "usurping all that falls in the vicinity of our black hole". An analethics is thus a bottom-centric scatological response to man's priapistic fantasies of bottomless violence. This ethics of anality is a barebacking ethics from the vantage point and for the benefit of the gangbangable body, where LGBT militancy would try a very different politics, in which all would go inside, all would be received, all would be allowed to penetrate so that we would "release shit and farts (...)".

This new queer politics would embrace the reality of sex, and not its realness, by surrendering to the inexorable instrumentality of bodies and their one-sided needs of circulation, refusing "exchange, dialogue, and negotiation" (Sáez \& Carrascosa, 2011: 69).

We might imagine how this analethical stance can spill over onto (social) dynamics beyond the sex scene - dynamics that shape the gangbang, but are not necessarily infected back by it. This is an active anality where the ass gets to choose its objects and functions, and it chooses all. Here the ass speaks back to genitalized sexual difference, universalizing the subject as a wounded subject of a lack whose sheltering, or hospitality, defies and signifies passivity and open- 
ness. In this analethic economy, brotherhoods would be disarmed because by extending kinship to all anus-bearing subjects there would be no-one else left to become a target.

\section{Surrendering to Semblance, Retreating to Bottomlessness}

On the libertine French site Netechangisme, several of the profiles feature duos and groups of male friends who share the same single account as they look for potential (female and trans) partners together - even if the interface itself only allows for joint accounts featuring one male and one female. Troifoisplus ("Threetimesmore"), for instance, presents itself as " 3 young men (19, 21 and 23 years old): Mathieu, Sofiane and Enzo for single or group encounters for providing women pleasure". In the users' comments associated with their account, where past lovers can leave performance reviews akin to those on Yelp, leagourmande ("greedy Lea"), a t-girl, praises the men as being an equipe de choc, that is, a dream team, or more literally, the type of helmet and body armour worn by police forces responsible for dispersing crowds. One of their techniques is to line up along the extremities of a street, as though they form a wall, and to move slowly towards the congregated men. Bukkorgang is one of several profiles that call themselves organizers of threeways, gangbangs (pluralité masculine), cuckold sessions, and back-to-back blowjobs (pipalachaine), that is pipes à la chaine. Pipes means "blowjobs" in French and à la chaine means "one after the other" but also "assembly-line work". ${ }^{17}$

The Brazilian roda de samba also illustrates the dynamic behind the gangbang's equipe de choc in its labouring woman (and man) into being - an example of what Preciado calls a cybernetics of power, in which power circulates through shared performative fictions that are transmitted from body to body like electric loads (Preciado, 2008: 317). The roda de samba is a manifestation of working class culture, normally associated with the slums of Rio de Janeiro. It traditionally consists of various male musicians sitting in a circle, drinking, riffing and improvising songs not unlike a jazz jam session. The lyrics to these sambas tend to sing the praises of traditional gender roles and the female form with impromptu and rhyming double entendres that lead to male laughter and bonding.

${ }^{17}$ Jc-lyon, who organizes regular events feature "one woman + transvestite +3 or 4 bisexual friends (35 to 60 years old)," claims to have "a stock of about fifteen buddies so it is easy to find some that are available." 
While the men sing, women dance in the middle of the roda (circle) of men holding their instruments. The woman's function in the roda de samba is that of a travelling target, a mobile eye-candy somewhere between a spinning top and a rotating bottle in a truth-or-dare game that keeps the men from having to stare at one another. ${ }^{18}$ As an excitation and shielding device, she is a reminder and a justification of the men's congregated multiplicity. She brings them together whilst keeping them from sticking together. Hers is a prophylactic function, maintaining men's relational status and barring contagion.

The gangbang's exceptional status - it is an event that is at once heterosexual and queer - speaks to the totemic feast as its excitement also lies in the rarity of its manifestation. We tend to think of the gangbang as an unusual event, in its violence, excitement and frequency. The gangbang is a carnivalesque holiday. As a Craigslist responder told me in Las Vegas once, in order to justify his asking me if he could bring his buddy along to my hotel room, "We are in Vegas, so we are like, what the hell, let's fuck a shemale together".

The gangbang works as an air pocket in the quotidian chokehold of a system of otherwise draconian maneuvering in which the Father is as dead as he is ironclad as a ghostly presence. The Father's absence is his "deification", turning him into a coding metastasis, which instructs everything, bringing cohesion from scene to scene into a sequence, in a way that his non-virtual presence never could. To the question, "What is the father?" Freud replies, "It is the dead father." (Freud, 2011: 135). His annihilation is the guarantee that he will never arrive to vex the virtues held up by His image. Ironically, a Fatherless society becomes a patriarchic one (Lacan, 2006: 688).

What Freud calls the "inciting factors" of the primordial disposing of the Father, guilt over the Father's murder and defiance over his authority, have lasted through generations as a kind of damned inheritance, or a symbolic DNA. This is illustrated, for instance, in the persistence of religion and monarchies throughout history, with their god and godlike fatherly figures, and the repetitive rituals without end associated with them. For Lacan, the Father's castration leads to him "being nothing but a number", which is "indicated quite clearly in dynasties" (Lacan, 1971: 14). The gangbang functions, then, as an uncanny re-appearance. When considering the uncanny, Freud stresses the element of

\footnotetext{
${ }^{18}$ Netechangisme user pachour22 tells me, "my goal is that you become my sex toy for myself and my friends". Private communication in chatroom, retrieved from Netechangisme.com (2014, February 20).
} 
an unsettling return of something familiar, which had been kept hidden. He also relates the uncanny to infantile fantasies of the double (an imagined lost twin sibling a child may imagine), which the gangbang multiplies into triples and more, and which appears as "an insurance against destruction of the ego", a denial of the irreversible power of death (Freud, 1919: 9).$^{19}$

The manifestation of ambivalence that drove the brotherly rebellion against the Father, as we have seen, simultaneously reconciles and re-enacts the murder for which the brothers seek expiation; as in the law of retaliation in which "a murder can be atoned only by the sacrifice of another life", which can also work as a blueprint for understanding the addictive function of cruising writ large, and barebacking in particular. In his seminal essay "Matan a Una Marica" ("A Faggot Is Being Murdered"), Perlongher (1997: 36) lists gay hate crimes and AIDS as outsourced rites of sacrifice and penitence that produce a pragmatic eradication of otherness and the (not so) secret pleasure that accompanies it. ${ }^{20}$

The bodily sites that remind the subject of his own lack, that is, of his own death, what Haver (1996: 12) calls "the body's lamellae" (i.e., the ears, the vagina, and above all, the anus) are violently stuffed in another disavowing coup. When the gangbanged body is that of a t-girl, the aim comes into focus more clearly, as she represents not only anality, but also liminality itself. As a visibly wounded site, the t-girl is the gangbang's ultimate target as a symbolic and material bearer of the very failure of "corporeal integrity of the so-called self". The gangbanged body being that of the t-girl is also exacerbated, as she represents bodily lamellae (she is a hole, one hole is all she has), by associations with "infection" and "otherness "itself", which Haver links to the said lamellae as unsettling "surfaces that are both inside and outside (...)" (Haver, 1996: 12). ${ }^{21}$

In the gangbang scene not only is the power of the penis, the representative of the phallus in practice - its fictive animation - multiplied by the number of them in the room, but the introduction of a third (and fourth, and so on, through physical or digital sharing) male body in the session legitimizes the $\mathrm{t}$ -

\footnotetext{
${ }^{19}$ Juliet Mitchell (2003) argues that siblings (in reality and in fantasy) introduce the child to seriality and death anxiety: Where do I go now that there is another one of me?

${ }^{20}$ Fethi Benslama sees in the figure of the "über-muslim" ("surmusulman") terrorists for whom the kinship-making injunction to attack is not about becoming but regressing to the past, a similar kind of expiation through annihilation, or sacrifice, "[s] uch terror aims to reveal a destructive force that dreads nothing (...)" (Benslama, 2016: 19, my translation).

${ }^{21}$ On the ears as unsettling lamellae, we might recall the multiplicity of men's laughter during a gangbang, and their conversations amongst themselves as though a $(\mathrm{t}-)$ girl was not in the room.
} 
girl further as a her, and not a gender-neutral you. One man is thus able to refer to the t-girl by addressing someone else, forcing the gender-defining pronoun she to be uttered, whereas if there were only one man and one t-girl in the scene, the gender-neutral you would be the only pronoun possible - language failing to wound the t-girl enough to publicly inscribe her as woman. That is an event of language -with incredible (meta-)physical consequences in which bearing (the make-up, the accouterments, the lack) is being. As such, the same event can hold vastly distinct functions as it works as a re-enactment for the man but, at the same time, as the t-girl's first entrance into the symbolic system in some ways founded by the great misdeed.

Like fire starters, the male multiplicity locks the t-girl's feminine position into place once her mediating presence locks them into relation. "The pussy is never yours... It's just your turn!" says the Internet meme. ${ }^{22}$ As one Craigslist trick said to another right before cumming inside me, "This bitch would be a nigga's best friend in jail...". Here, "this bitch" holds the gender notarization function that a "she" guarantees when the t-girl is stuck not before man but between men.

This setup authenticates the t-girl as a woman through the male multitude's speech. When one man addresses another man in reference to her, he performs not only the function of "speaking to or about someone" but, and most importantly, a "way of approaching another such that one presumes who the other is, even the meaning and value of their existence", as Judith Butler puts it in response to an unarmed black man addressing the (police) State with "Black Lives Matter", a way of saying "You - white police officers - recognize my/our humanity!" (Butler, 2015).

In the gangbang, where a multiplicity of men (re-)gender a ( $\mathrm{t}$-) girl into place by the uttering she or her, and by sharing her body as they would a meal, the tone they use to hail each other reveals a belittlement of the negotiated feminine object-cum-female target. This belittlement reiterates she-ness as a filament, if not a net, safeguarding the men from taking each other for a she (Butler, 2015).

If the gangbang is thus an event in language in which ambivalence is resolved, the digital is a network where age-old anxieties over ambivalence re-emerge, bearing the trace and the veering of their original violence but also teeming with opportunities for the re-claiming, or re-coding, of that very vio-

\footnotetext{
${ }^{22}$ Retrieved from http://memegenerator.net/instance/53728866.
} 
lence. The gangbang, and the gangbang with a t-girl as its target in particular, is at once reactionary and subversive; it laughs with and laughs at the coding that makes its engendering possible. The gangbang is realistic. It makes good use of the code, computational and psychic, in order to find pleasure where it can. The gangbang does not re-write; it reads between the lines. The gangbang is ultimately trans-sexual, even if a t-girl is not its literal target, for its very dynamic exposes the functional role of each body, any body, in a sexual encounter. Driving the gangbang is a politics of survival where even if, or especially if, the materiality of the body is seen to deny such survival from the t-girl: bodily functions matter, not matter itself. Matter disappears, only fantasy is left, along with bits of bones, mounds of flesh, holes (avowed and disavowed), and the promise of never-ending fluids, like an entirely repaired spring-like breast that never dries up.

I have pointed to the male collective as the agents of what we could call an archaic and infantile need to destroy and to repair, to destroy as a way of making reparation. I have also established the figure of the digitally enabled t-girl as a spectre of re-signifying creativity, enjoyment and the hacker ethic. As such, the backend of networked communications (the digital) is not only intimately entwined with the backend of psychic structures (the unconscious) but they also abide by mirroring architecting powers and emanate corresponding analytical value. The digitally mediated gangbang is an emblematic instantiation of the network's own orgiastic relationship to the data flows that constitute it. The gangbang is, then, a case of the heterosexual symbolic running at once at its most normative and its queerest, allowing unprecedented access to the way dominant forms of code perform themselves and to imagining techniques of enjoyment in the face of the pre-determining propensity of all code. The gangbang bugs the system without bringing it to a halt, making room for non-utopian possibilities of enjoyment that make a mockery of the body as a bounded individual entity and of the future as something other than a cock-blocking operation (Shah, 2015). 


\section{References}

Benslama, F. (2016). Le Surmusulman: Un Furieux Désir de Sacrifice. Paris: Seuil.

Berlant, L. (2006). Cruel Optimism. Differences: A Journal of Feminist Cultural Studies, 17(3): 20-36.

Butler, J. (2015, 12 January). What's Wrong With 'All Lives Matter'? The New York Times. Accessed 01. 05. 2015. URL: http://opinionator.blogs.nytimes. com/2015/01/12/whats-wrong-with-all-lives-matter/\#more-155504.

Chun, W. (2016). Updating to Remain the Same: Habitual New Media. Boston: The MIT Press.

Crandall, K. (2011). Ontologies of the Wayward Drone. CTheory. Accessed 01. 05. 2015. URL: http://ctheory.net/articles.aspx?id=693.

Debord, G. (2014). The Society of the Spectacle: Annotated Edition. Bureau of Public Secrets.

Despentes, V. (2006). King Kong théorie. Paris: Grasset.

Dollimore, J. (2001). Sexual Disgust. In Dean, T. \& Lane, C. (ed.), Homosexuality \& Psychoanalysis (pp. 367-386). Chicago and London: The University of Chicago Press.

Foucault, M. (1977). Nietzsche, Genealogy, History. In Bouchard, D. F. (ed.), Language, Counter-Memory, Practice: Selected Essays and Interviews (pp. 139-164). Ithaca: Cornell University Press.

Freud, S. (2011). Civilization \& Its Discontents. Martino Publishing.

Freud, S. (1919). The 'Uncanny'. Imago, 5(5-6): 297-324.

Freud, S. (2013). Totem and Taboo. New York: Empire Books.

Giard, A. (2015, 01 October) Pourquoi Les Bruits de Sécretion Excitent? [Why Do Secretion Noises Turn Us On?]. Libération, "Les 400 Culs"]. Accessed 10. 04. 2015. URL: http://sexes.blogs.liberation.fr/agnes_giard/2014/10/il-y-atoujours-une-forme-de-traumatisme-avec-la-sexualit\%C3\%A9-on-a-beau- 
Digitality, Psychoanalysis and the Gangbang

avoir-\%C3\%A9tudi\%C3\%A9-les-organes-g\%C3\%A9nitaux-\%C3\%A01\%C3\%A9cole-et.html.

Grigg, R. (2014, 26 November). Why Freud's Theory of Melancholia is All Wrong [audio from lecture at Kingston University]. Accessed 15. 03. 2015. URL: http://backdoorbroadcasting.net/2014/11/russell-grigg-why-freuds-theoryof-melancholia-is-all-wrong/.

Halberstam, J. (2011). The Queer Art of Failure. Duke University Press.

Haver, W. (1996). The Body of This Death: Historicity and Sociality in the Time of AIDS. Stanford University Press.

Klein, M. (1988). Love, Guilt and Reparation: And Other Works 1921-1945. London: Virago.

Lacan, J. (2006). Écrits. New York and London: W. W. Norton \& Company.

Lacan, J. (1971). The Seminar of Jacques Lacan, Book XVIII: On A Discourse That Might Not Be a Semblance (1971). (C. Gallagher, trans.). Accessed 03. 02 .2017. URL: http://www.valas.fr/IMG/pdf/THE-SEMINAR-OFJACQUES-LACAN-XVIII_d_un_discours.pdf.

Leiner, D. (Director). (2000). Dude, Where's My Car? [Motion picture on DVD]. USA.

Mbembe, A. (2003). Necropolitics. Public Culture, 15(1): 11-40.

McPherson, T. (2012). U.S. Operating Systems at Mid-century: The Intertwining of Race and UNIX. In Nakamura, L., Chow-White, P. \& Nelson, A. (eds.), Race after the Internet (pp. 21-37). New York: Routledge.

Mitchell, J. (2003). Siblings: Sex and Violence. Cambridge, UK: Polity.

Moraes, C. (2016, 07 June). Compartilhar estupro coletivo nas redes, a nova versão da barbárie brasileira. El País. Accessed 07. 06. 2016. URL: http:// brasil.elpais.com/brasil/2016/05/26/politica/1464275134_153470.html.

Paasonen, S. (2011). Carnal Resonance: Affect and Online Pornography. Cambridge, MA: MIT Press.

Perlongher, N. (1997). Prosa Plebeya: Ensayos 1980-1992. Buenos Aires: Ediciones Colihue S.R.L. 
Phillips, W. (2015). This Is Why We Can't Have Nice Things: Mapping the Relationship between Online Trolling and Mainstream Culture. Boston: The MIT Press.

Preciado, B. (2000). Manifeste Contra-Sexuel. Paris: Balland.

Preciado, B. (2008). Testo Junkie: Sexe, Drogue et Biopolitique. Paris: Grasset.

Sáez, J. \& Carrascosa, S. (2012). Por El Culo: Politicas Anales. Barcelona and Madrid: Egales.

Salamon, G. (2010). Assuming a Body: Transgender and Rhetorics of Materiality. New York: Columbia University Press.

Shah, N. (2015). The Selfie and the Slut: Bodies, Technology and Public Shame. Economic \& Political Weekly, 50(17): 86-93.

Silverman, K. (1986). Fragments of a Fashionable Discourse. In Modleski, T. (ed.), Studies in Entertainment: Critical Approaches to Mass Culture (pp. 139-152). Bloomington, IN: Indiana University Press.

Winch, A. \& Hakim, J. (2017, forthcoming). 'I'm Selling the Dream Really aren't I?': Sharing Fit Male Bodies on Social Networking Sites. In McGillivray, D., McPherson, G. \& Carnicelli, S. (eds.), Digital Leisure Cultures: Critical Perspectives. London: Routledge. 
The Female Target:

Digitality, Psychoanalysis and the Gangbang 